\title{
The Co-ordination and Cleavage Reactions of Aluminium Borohydride with Ligands containing Elements from Groups $\mathrm{V}$ and $\mathrm{VI}$
}

\begin{abstract}
By P. H. Bird and M. G. H. Wallbridge, Department of Chemistry, The University, Sheffield 10
Aluminium borohydride reacts with triphenylphosphine to form initially a $1: 1$ adduct; subsequent addition of excess of ligand causes decomposition of this adduct, and results in cleavage of the $\mathrm{AlH}_{2} \mathrm{~B}$ bridges. With ammonia the initial reaction product is a $1: 2$ adduct, $\mathrm{Al}\left(\mathrm{BH}_{4}\right)_{3}, 2 \mathrm{NH}_{3}$, but here excess of ligand cleaves the $\mathrm{AlH} \mathrm{H}_{2} \mathrm{~B}$ bridges unsymmetrically, and the final product is best formulated as $\left[\mathrm{Al}\left(\mathrm{NH}_{3}\right)_{6}\right]^{3}+\left(\mathrm{BH}_{4}^{-}\right)_{3}$. The relative strengths of the co-ordinate bond in a series of $1: 1$ adducts have been studied by displacement reactions which show $\mathrm{NMe}_{3} \sim$ $\mathrm{PMe}_{3}>\mathrm{AsMe}_{3}$ and $\mathrm{Me}_{2} \mathrm{O}>\mathrm{Me}_{2} \mathrm{~S}$. The similarity in the nitrogen and phosphorus compounds is discussed with relevance to the formation of $1: 2$ adducts in these cases.
\end{abstract}

ALUMINIUM BOROHYDRIDE reacts with a variety of ligands, containing donor atoms of Groups V and VI, forming initially a $1: 1$ adduct of the type $\mathrm{L} \rightarrow \mathrm{Al}\left(\mathrm{BH}_{4}\right)_{3}(\mathrm{~L}=$ ligand $)$, where the ligand atom is bonded to the aluminium atom. ${ }^{1}$ Further addition of ligand may cause cleavage of the $\mathrm{AlH}_{2} \mathrm{~B}$ bridge bonds depending on the particular ligand atom involved. This Paper describes reactions of aluminium borohydride with triphenylphosphine and ammonia.

Equimolar quantities of aluminium borohydride and triphenylphosphine react with the formation of a $1: 1$ adduct, $\mathrm{Ph}_{3} \mathrm{P} \rightarrow \mathrm{Al}\left(\mathrm{BH}_{4}\right)_{3}$, which is monomeric in benzene solution. The complex partially liquefies at $101^{\circ}$ when heated, and further melting may be observed at $186^{\circ}$, suggesting initial decomposition of the complex to form triphenylphosphine-borane; the residual involatile material showed very broad absorptions in the infrared spectrum at $\sim 1800$ and $800 \mathrm{~cm}^{-1}$, presumably due to bridging $\mathrm{Al}-\mathrm{H}-\mathrm{Al}$ groups.

The thermal decomposition of aluminium borohydride-

1 P. H. Bird and M. G. H. Wallbridge, J. Chem. Soc., 1965, 3923.

${ }^{2}$ H. I. Schlesinger, R. T. Sanderson, and A. B. Burg, $J$. Amer. Chem. Soc., 1940, 62, 3421. trimethylamine has been suggested ${ }^{2}$ to occur as reaction (1)

$$
\mathrm{Al}\left(\mathrm{BH}_{4}\right)_{3}, \mathrm{NMe}_{3} \rightleftharpoons\left[\mathrm{HAl}\left(\mathrm{BH}_{4}\right)_{2}\right]+\mathrm{BH}_{3}, \mathrm{NMe}_{3}
$$

and the decomposition of the $1: 1$ adduct with triphenylphosphine is probably similar initially:

$$
\mathrm{Al}\left(\mathrm{BH}_{4}\right)_{3}, \mathrm{PPh}_{3} \longrightarrow\left[\mathrm{HAl}\left(\mathrm{BH}_{4}\right)_{2}\right]+\mathrm{BH}_{3}, \mathrm{PPh}_{3}
$$

However, in this case the product $\mathrm{HAl}\left(\mathrm{BH}_{\mathbf{4}}\right)_{\mathbf{2}}$ is unstable and rapidly disproportionates, probably by routes $(2)$ and $(3)$

$$
\begin{aligned}
& 3\left[\mathrm{HAl}\left(\mathrm{BH}_{4}\right)_{2}\right] \longrightarrow\left(\mathrm{AlH}_{3}\right)_{n}+2 \mathrm{Al}\left(\mathrm{BH}_{4}\right)_{3} \\
& 2\left[\mathrm{HAl}\left(\mathrm{BH}_{4}\right)_{2}\right] \longrightarrow\left[\mathrm{H}_{2} \mathrm{AlBH}_{4}\right]_{n}+\mathrm{Al}\left(\mathrm{BH}_{4}\right)_{3}
\end{aligned}
$$

since aluminium borohydride was recovered from the pyrolysis. It is interesting to consider the results obtained by Ogg and $\operatorname{Ray}^{\mathbf{3}}$ on heating samples of aluminium borohydride at $80^{\circ}$ for 10 hours, in the light of reactions (2) and (3). After rapidly cooling their samples, the nuclear magnetic resonance (n.m.r.) spectra at room temperature showed marked differences from that of aluminium borohydride. Since diborane was 239. 
detected, and the samples slowly reverted to the borohydride on standing, the equilibrium

$$
2 \mathrm{Al}\left(\mathrm{BH}_{4}\right)_{3} \rightleftharpoons \mathrm{Al}_{2} \mathrm{~B}_{4} \mathrm{H}_{18}+\mathrm{B}_{2} \mathrm{H}_{6}
$$

was proposed, and the structure of $\mathrm{Al}_{2} \mathrm{~B}_{4} \mathrm{H}_{18}$ was postulated as (I), containing an $\mathrm{AlH}_{2} \mathrm{Al}$ bridge system, i.e.,<smiles>[B]C[CH][AlH][Al](CB)[AlH]C[B]</smiles>

$\left(\mathrm{BH}_{4}\right)_{2} \mathrm{AlH}_{2} \mathrm{Al}\left(\mathrm{BH}_{4}\right)_{2}$. The existence of $\mathrm{Al}_{2} \mathrm{~B}_{4} \mathrm{H}_{18}$ at $80^{\circ}$ seems extremely unlikely in view of the instability, even at $20^{\circ}$, of the species formed as in reaction (la), and two attempts to prepare the material obtained by Ogg and Ray failed. These results are incompatible with those of Ogg and Ray, and suggest that if an equilibrium of type (4) is involved at $80^{\circ}$ then the system rapidly reverts to aluminium borohydride on cooling.

The complex $\mathrm{Al}\left(\mathrm{BH}_{4}\right)_{3}, \mathrm{PPh}_{3}$ was not sufficiently soluble in organic solvents for n.m.r. spectra to be obtained for the borohydride protons, and conclusions concerning the structure of the complex are therefore made from the infrared spectrum, and comparison with other $1: 1$ complexes. Thus, the infrared spectrum is very similar to those of the other $1: 1$ complexes, $^{1}$ indicating the presence of borohydride groups bonded to the aluminium atom through $\mathrm{AlH}_{2} \mathrm{~B}$ bridging groups. The terminal $\mathrm{B}-\mathrm{H}$ stretching mode appears at 2505 and $2440 \mathrm{~cm}^{-1}$, and the $\mathrm{BH}_{2}$ terminal deformation mode at $1112 \mathrm{~cm}^{-1}$, whilst in addition two vibrations associated with the bridging hydrogen atoms occur at 2132 and $1484\left(\right.$ ?) $\mathrm{cm}^{-1}$, although the band at $1484 \mathrm{~cm}^{-1}$ is partly obscured by bands arising from the triphenylphosphine. Since in the other $1: 1$ adducts the ligand atom is bonded to the aluminium atom it is not unreasonable to suggest a similar structure in this case. The stretching mode of the $\mathrm{Al} \leftarrow \mathrm{P}$ bond is not observed in the $4000-400$ $\mathrm{cm} .^{-1}$ region.

The expected cleavage products from reaction of the $\mathbf{l}: \mathbf{l}$ adduct with a further $1 \mathrm{~mol}$. of triphenylphosphine could not be isolated. Instead, a colourless gum-like material was obtained whose infrared spectrum showed only weak $\mathrm{B}-\mathrm{H}$ terminal and bridge stretching modes but contained a series of broad absorptions from $\sim 1700$ down to $400 \mathrm{~cm} .{ }^{-1}$ indicating extensive $\mathrm{Al}-\mathrm{H}-\mathrm{Al}$ bridging. From cryoscopic measurements it was possible to deduce the probable stoicheiometry of the reaction as

$$
\mathrm{Al}\left(\mathrm{BH}_{4}\right)_{3}, \mathrm{PPh}_{3}+\mathrm{PPh}_{3} \stackrel{\text { benzene }}{\longrightarrow}\left[\mathrm{H}_{2} \mathrm{AlBH}_{4}\right]_{n} \downarrow+2 \mathrm{BH}_{3}, \mathrm{PPh}_{3}
$$

since it is known that borane-triphenylphosphine is monomeric in benzene solution. ${ }^{4}$

The reaction of ammonia with aluminium borohydride has been previously investigated, but no definite conclusions regarding the products nave been made.

${ }^{4}$ L. Banford and G. E. Coates, J. Chem. Soc., 1964, 5591.

5 L. Taylor, U.S. Dept. Comm., Office Tech. Serv., 1961, A.D., 256,887 , pp. $30-32$.

6 W. C. Price, J. Chem. Phys., 1949, 17, 1044.
Thus, Schlesinger et al. ${ }^{2}$ and Taylor ${ }^{5}$ reported that 1 mole of aluminium borohydride reacts with 4 and 6 moles of ammonia, respectively, producing an amorphous white solid. The present investigation has confirmed that a total of 6 moles of ammonia react, but that the initial reaction is anomalous compared with the other ligand reactions in that a $1: 1$ adduct could not be isolated. When the reactants are mixed in a $1: 1$ mole ratio the product corresponds to $\mathrm{Al}\left(\mathrm{BH}_{4}\right)_{3}, 2 \mathrm{NH}_{3}$, half of the aluminium borohydride remains unreacted, and, unlike the $1: 2$ adducts with trimethylamine and trimethylphosphine (see below), this $1: 2$ adduct is stable indefinitely at $20^{\circ}$. Excess of ammonia reacts with aluminium borohydride, or with the $1: 2$ adduct, to produce a compound with the empirical formula $\mathrm{Al}\left(\mathrm{BH}_{4}\right)_{3}, 6 \mathrm{NH}_{3}$. This is also stable at $20^{\circ}$, it reacts only slowly with water, and is insoluble in hydrocarbon solvents but is moderately soluble in liquid ammonia. The infrared spectrum of this material is extremely simple, having single bands at 2260 and $1100 \mathrm{~cm}^{-1}$ typical of a $\mathrm{BH}_{4}{ }^{-}$ion, ${ }^{6}$ and at 3250,1620 , and $1350 \mathrm{~cm}^{-1}$ typical of $\mathrm{N}-\mathrm{H}$ stretching and $\mathrm{NH}_{2}$ deformation modes. The proton n.m.r. spectrum obtained from a solution of the product in ammonia at $-40^{\circ}$ shows a quartet (relative intensities $1: 1: 1: 1$ ), also consistent with the presence of a $\mathrm{BH}_{4}{ }^{-}$ion. The product therefore appears to be better formulated as $\left[\mathrm{Al}\left(\mathrm{NH}_{3}\right)_{6}\right]^{3+}\left(\mathrm{BH}_{4}{ }^{-}\right)_{3}$. The bands associated with the $\mathrm{NH}_{3}$ groups occur at 3250, $3200,1620,1350,795$, and $483 \mathrm{~cm}^{-1}$, and agree closely with values for other typical octahedral hexa-ammine complexes. ${ }^{7}$ The weak band at $483 \mathrm{~cm}^{-1}$ in the product may be assigned as an Al-N stretching mode $\left(F_{1 u}\right)$ expected for an octahedral complex. The other infrared-active mode is a deformation vibration $\left(F_{1 u}\right)$ which would be expected to lie below $400 \mathrm{~cm}^{-1}$. The formulation above is further supported by several reactions of the complex. Ammonium chloride in ammonia reacts with the borohydride ion, and such a reaction assists in establishing the presence of ${\mathrm{a} \mathrm{BH}_{4}^{-}}^{-}$ion in the diammoniate of diborane: $\mathbf{~}^{\mathbf{8} 9}$

$$
\begin{aligned}
& \mathrm{BH}_{4}{ }^{-}+\mathrm{NH}_{4} \mathrm{Cl} \longrightarrow \mathrm{NH}_{4} \mathrm{BH}_{4}+\mathrm{Cl}^{-} \\
& \mathrm{NH}_{4} \mathrm{BH}_{4} \longrightarrow \mathrm{H}_{3} \mathrm{~N}_{3} \mathrm{BH}_{3}+\mathrm{H}_{2} \\
& \mathrm{H}_{3} \mathrm{~N}_{1} \mathrm{BH}_{3}+\mathrm{NH}_{4} \mathrm{Cl} \longrightarrow\left[\left(\mathrm{H}_{3} \mathrm{~N}_{2}\right)_{2} \mathrm{BH}_{2}\right] \mathrm{Cl}+\mathrm{H}_{2} \\
& {\left[\left(\mathrm{H}_{3} \mathrm{~N}\right)_{2} \mathrm{BH}_{2}\right] \mathrm{BH}_{4}+2 \mathrm{NH}_{4} \mathrm{Cl} \longrightarrow 2\left[\left(\mathrm{H}_{3} \mathrm{~N}\right)_{2} \mathrm{BH}_{2}\right] \mathrm{Cl}+2 \mathrm{H}_{2}}
\end{aligned}
$$

Aluminium borohydride hexa-ammine reacts with ammonium chloride in ammonia, producing near 6 moles of hydrogen per mole of the ammine, and by analogy with the above reaction scheme the reaction may be postulated as

$$
\begin{aligned}
& {\left[\mathrm{Al}\left(\mathrm{NH}_{3}\right)_{6}\right]\left(\mathrm{BH}_{4}\right)_{3}+6 \mathrm{NH}_{4} \mathrm{Cl} \longrightarrow} \\
& {\left[\mathrm{Al}\left(\mathrm{NH}_{3}\right)_{6}\right] \mathrm{Cl}_{3}+3\left[\left(\mathrm{H}_{3} \mathrm{~N}\right)_{2} \mathrm{BH}_{2}\right] \mathrm{Cl}+6 \mathrm{H}_{2}}
\end{aligned}
$$

7 Nakamoto, "Infrared Spectra of Inorganic and Coordination Compounds," Wiley, New York, 1963, sect., $111-1$.

8 D. R. Schultz and R. W. Parry, J. Amer. Chem. Soc., 1958, 80, 4 .

80,8 . 
The reaction of the hexa-ammine with lithium (or sodium) in ammonia is interesting in that it might have been expected to produce $1 \frac{1}{2}$ moles of hydrogen per mole of ammine according to the equation:

$$
\begin{aligned}
{\left[\mathrm{Al}\left(\mathrm{NH}_{3}\right)_{6}\right]\left(\mathrm{BH}_{4}\right)_{3}+3 \mathrm{Li} } & \longrightarrow \mathrm{Al}\left(\mathrm{NH}_{2}\right)_{3}+3 \mathrm{LiBH}_{4}+\frac{3}{2} \mathrm{H}_{2}+3 \mathrm{NH}_{3} \\
\text { c.f. }\left[\mathrm{H}_{2} \mathrm{~B}\left(\mathrm{NH}_{3}\right)_{2}\right] \mathrm{BH}_{4}+\mathrm{Na} & \longrightarrow \mathrm{H}_{2} \mathrm{~B}, \mathrm{NH}_{2}+\mathrm{NaBH}_{4}+\frac{1}{2} \mathrm{H}_{2}+\mathrm{NH}_{3}
\end{aligned}
$$

since the reaction of the diammoniate of diborane with sodium in ammonia takes place through the rupture of nitrogen-hydrogen bonds only. ${ }^{8}$ However, under no conditions could more than 1 mole of hydrogen be obtained. Taylor et al. ${ }^{10}$ titrated ammonium iodide with potassium in ammonia, but here the reaction ceased after the addition of $\sim 1 \cdot 6$ moles of potassium per mole of aluminium iodide. The overall reaction was postulated as

$$
\left[\mathrm{Al}\left(\mathrm{NH}_{3}\right)_{6}\right] \mathrm{I}_{3}+2 \mathrm{~K} \longrightarrow \mathrm{Al}\left(\mathrm{NH}_{2}\right)_{2} \mathrm{l}+2 \mathrm{KI}+4 \mathrm{NH}_{3}+\mathrm{H}_{2}
$$

It was suggested that the low value for the potassium was due to the impure state of a sample of aluminium iodide. In the present investigation 1 mole of the borohydride hexa-ammine reacted with 2 moles of lithium. Whilst the residue was expected to be $\mathrm{Al}\left(\mathrm{NH}_{2}\right)_{2} \mathrm{BH}_{4}$ it proved to be $\operatorname{Li}\left[\mathrm{Al}\left(\mathrm{NH}_{2}\right)_{2}\left(\mathrm{BH}_{4}\right)_{2}\right]$ in which the aluminium is probably tetrahedrally surrounded in the ion $\left[\mathrm{Al}\left(\mathrm{NH}_{2}\right)_{2}\left(\mathrm{BH}_{4}\right)_{2}\right]^{-}$as in LiAlEt ${ }_{4}{ }^{11}$ A tentative proposal to explain the stability of $\mathrm{Al}\left(\mathrm{NH}_{2}\right)_{2} \mathrm{BH}_{4}$ could be that, since the $\mathrm{Al}\left(\mathrm{NH}_{2}\right)_{2}{ }^{+}$ion is isoelectronic with allene, $\mathrm{CH}_{2}=\mathrm{C}=\mathrm{CH}_{2}$, it could be stabilised as $\left(\mathrm{H}_{2} \mathrm{~N} \rightrightarrows \mathrm{Al} \leftarrow \mathrm{NH}_{2}\right)^{+}$.

As well as forming the $1: 2$ adduct initially with ammonia, aluminium borohydride will also combine with trimethylamine and trimethylphosphine to form adducts with the empirical formulæ $\mathrm{Al}\left(\mathrm{BH}_{4}\right)_{3}, 2 \mathrm{NMe}_{3}$ and $\mathrm{Al}\left(\mathrm{BH}_{4}\right)_{3}, 2 \mathrm{PMe}_{3}$, as previously reported. ${ }^{12}$ Whilst it is possible that any ligand might form a $1: 2$ adduct at sufficiently low temperature, many are not sufficiently volatile for absorption of excess of ligand to be detected, e.g., at $-78^{\circ}$, but no further reaction beyond the $1: 1$ stage was detected for dimethyl ether. Both $1: 2$ adducts, $\mathrm{Al}\left(\mathrm{BH}_{4}\right)_{3}, 2 \mathrm{NMe}_{3}$ and $\mathrm{Al}\left(\mathrm{BH}_{4}\right)_{3}, 2 \mathrm{PMe}_{3}$, are unstable at room temperature under a vacuum, but reasonably stable under nitrogen. The products of decomposition are the $1: 1$ adduct and free ligand [reaction (6)], together with products arising from the cleavage reactions, i.e., borane-trimethylamine, or borane-trimethylphosphine, and hydride aluminium borohydride [reaction (7)].

$$
\begin{aligned}
\mathrm{Al}\left(\mathrm{BH}_{4}\right)_{3}, 2 \mathrm{~L} \longrightarrow & \longrightarrow \mathrm{Al}\left(\mathrm{BH}_{4}\right)_{3}, \mathrm{~L}+\mathrm{L} \\
\left(\mathrm{L}=\mathrm{NMe}_{3} \text { or } \mathrm{PMe}_{3}\right) & \mathrm{HAl}\left(\mathrm{BH}_{4}\right)_{2}, \mathrm{~L}+\mathrm{BH}_{3}, \mathrm{~L}
\end{aligned}
$$

Provided that any ligand was removed immediately it was released, reactions (6) and (7) always occurred

10 W. L. Taylor, E. Griswold, and J. Kleinberg, J. Amer. Chem. Soc., 1942, 64, 316.

${ }_{11}$ R. L. Gertis, R. E. Dickerson, and J. L. Brown, Inovg. Chem., 1964, 3, 872 .

291 . simultaneously and to about the same extent, regardless of the temperature at which the $1: 2$ adduct was allowed to decompose.

Of the $1: 2$ adducts, only those with trimethylphosphine and ammonia could be investigated further at room temperature, but again no n.m.r. spectra could be obtained owing to insolubility of the adducts. Tentative deductions regarding the structure of these products can be made from their infrared spectra. In general features the spectra of both adducts resemble those of the $1: 1$ adducts, and are simpler inasmuch as the bridge stretching mode at $\sim 2150 \mathrm{~cm}^{-1}$ is sharper than in the $1: 1$ adducts. By comparison with the previous discussion for the aluminium hydride adducts $\mathrm{AlH}_{3}, \mathrm{NMe}_{3}$ and $\mathrm{AlH}_{3}, 2 \mathrm{NMe}_{3},{ }^{13}$ if in this case the aluminium atom is surrounded by three borohydride groups and two ligands in a monomeric molecule the preferred structure would be a trigonal bipyramid. Assuming the two ligands are placed at the apices, the structure would have $D_{3 h}$ or $D_{3}$ symmetry depending on whether the bridging hydrogen atoms are in the plane of the LAIB atoms ( $\mathrm{L}=$ ligand) or skewed out of this plane. As in the case of aluminium borohydride itself 6,14 it is not possible to distinguish between these two alternatives from the infrared spectrum alone, but the spectra appear to be consistent with at least the trimethylphosphine $\mathbf{1}: \mathbf{2}$ adduct having a trigonal bipyramidal structure. The use of aluminium borodeuteride has confirmed that in these compounds the bonds appearing at $\sim 2400$ and $\sim 1120 \mathrm{~cm}^{-1}$ may be assigned to the stretching and deformation modes of the terminal $\mathrm{BH}_{2}$ atoms of the borohydride group, and those at $\sim 2150$ and $\sim 1400 \mathrm{~cm}^{-1}$ to vibrations involving the bridge atoms $\mathrm{AlH}_{2} \mathrm{~B}$, such assignments having been previously discussed. ${ }^{1}$

Ammonia and triphenylphosphine further illustrate the variation in reaction with change of ligand molecule, and this contrasts with the previous examples of alkyl derivatives of the Group V and VI elements. ${ }^{1}$.Ammonia has a low steric requirement, and the existence of other hexa-ammine complexes, e.g., $\left[\mathrm{Al}\left(\mathrm{NH}_{3}\right)_{6}\right] \mathrm{X}_{3}(\mathrm{X}=\mathrm{Cl}$, $\mathrm{Br}$, or I), ${ }^{15}$ emphasises its effectiveness as a Lewis base with aluminium. The reaction described here may also be compared with that involving diborane, where unsymmetrical cleavage of the bridge bonds also occurs, yielding the diammoniate $\left[\left(\mathrm{NH}_{3}\right)_{2} \mathrm{BH}_{2}\right]^{+} \mathrm{BH}_{4}{ }^{-16}$ If this type of cleavage occurs initially with aluminium borohydride, then the $1: 2$ adduct could be alternatively formulated as $\left[\left(\mathrm{NH}_{3}\right)_{2} \mathrm{Al}\left(\mathrm{BH}_{4}\right)_{2}\right]^{+} \mathrm{BH}_{4}{ }^{-}$, and, whilst the infrared spectrum does show bands at 2270 and 1125 $\mathrm{cm}^{-1}$ (i.e., near those observed for the $\mathrm{BH}_{4}{ }^{-}$ion at 2270 and $1080 \mathrm{~cm}^{-1}$ ), further results are required to clarify this point. The reaction involving triphenylphosphine

13 G. W. Frazer, N. N. Greenwood, and B. P. Straughan, J. Chem. Soc., 1963, 3472.

14 A. R. Emery and R. C. Taylor, Spectrochim. Acta, 1960, 16, 1455 .

${ }_{15} \mathrm{~W}$. Klemm and E. Tanke, $Z$. anorg. Chem., 1931, 200, 343. 16 S. G. Shore and R. W. Parry, J. Amer. Chem. Soc., 1955, ry, 
Inorg. Phys. Theor.

suggests the initial formation of a weak $\mathrm{Al} \longleftarrow \mathrm{P}$ bond, with the further addition of ligand effecting symmetrical cleavage of the $\mathrm{AlH}_{2} \mathrm{~B}$ bridges, yielding $\mathrm{HAl}\left(\mathrm{BH}_{4}\right)_{2}, \mathrm{PPh}_{3}$ and borane-triphenylphosphine. If this borohydride adduct was then less stable than the initial $1: 1$ adduct, dissociation of the ligand would be followed by further cleavage reactions and precipitation of the dihydride $\left[\mathrm{H}_{2} \mathrm{Al}\left(\mathrm{BH}_{4}\right)\right]_{n}$ [reaction (5)]. The reduced stability of the $\mathrm{HAl}\left(\mathrm{BH}_{4}\right)_{2}, \mathrm{PPh}_{3}$ compound is reasonable since, whilst several $\mathbf{1}: \mathbf{1}$ adducts of aluminium borohydride exist, the corresponding derivatives of aluminium hydride are unstable (e.g., $\left.\mathrm{AlH}_{3}, \mathrm{NMe}_{3}\right)^{13}$ or unknown $\left(e . g \text {., } \mathrm{AlH}_{3}, \mathrm{PMe}_{3}\right)^{12,17}$

According to previous experimental evidence ${ }^{18}$ aluminium compounds are stronger Lewis acids towards trimethylamine than trimethylphosphine, thus trimethylaluminium appears to be a typical class (a) acceptor, as deduced from displacement reactions, showing a decreasing donor-acceptor bond strength in the order $\mathrm{NMe}_{3}>\mathrm{PMe}_{3}>\mathrm{AsMe}_{3}$ and $\mathrm{Me}_{2} \mathrm{O}>\mathrm{Me}_{2} \mathrm{~S}$. We have made a similar study using aluminium borohydride and quantitative displacement reactions show that trimethylphosphine displaces trimethylarsine, and dimethyl ether displaces dimethyl sulphide, from their respective $1: 1$ adducts. However, no definite conclusion may be drawn from the reactions involving trimethylamine and trimethylphosphine since, regardless of which displacement reaction is attempted, the products are always the same and are obtained in the same proportions:

$$
\begin{aligned}
\left.\mathrm{Al}\left(\mathrm{BH}_{4}\right)_{3}, \mathrm{NMe}_{3}+\mathrm{PMe}_{3}\right\} & \left.\begin{array}{rl}
\mathrm{Al}\left(\mathrm{BH}_{4}\right)_{3}, \mathrm{PMe}_{3}+\mathrm{NMe}_{3}
\end{array}\right\} \frac{\text { Closed system }}{20^{\circ}} \\
& \left\{\begin{array}{l}
\mathrm{HAl}\left(\mathrm{BH}_{4}\right)_{2}, \mathrm{PMe}_{3}+\mathrm{BH}_{3}, \mathrm{NMe}_{3} \\
+\mathrm{HAl}\left(\mathrm{BH}_{4}\right)_{2}, \mathrm{NMe}_{3}+\mathrm{BH}_{3}, \mathrm{PMe}_{3}
\end{array}\right.
\end{aligned}
$$

This may be understood in the light of the $1: 2$ adducts, discussed above, since the mixed $1: 2$ adduct, $\mathrm{Al}\left(\mathrm{BH}_{4}\right)_{3}, \mathrm{NMe}_{3}, \mathrm{PMe}_{3}$, may be prepared [in the same way as the adducts $\mathrm{Al}\left(\mathrm{BH}_{4}\right)_{3}, 2 \mathrm{NMe}_{3}$ and $\left.\mathrm{Al}\left(\mathrm{BH}_{4}\right)_{3}, 2 \mathrm{PMe}_{3}\right]$ from either of the $1: 1$ adducts, $\mathrm{Al}\left(\mathrm{BH}_{4}\right)_{3}, \mathrm{NMe}_{3}$ or $\mathrm{Al}\left(\mathrm{BH}_{4}\right)_{3}, \mathrm{PMe}_{3}$. This mixed adduct is intermediate in stability between the other $1: 2$ adducts, decomposing above $\sim-10^{\circ}$. In a closed system the products were identical with those obtained in the displacement reaction (8), but if the volatile products were removed as they were formed the cleavage reactions were in part prevented, and the decomposition may be represented as

$$
\begin{aligned}
\mathrm{Al}\left(\mathrm{BH}_{4}\right)_{3}, \mathrm{NMe}_{3}, \mathrm{PMe}_{3} \underset{\text { vacuum }}{\stackrel{-10^{\circ} \longrightarrow}{\longrightarrow}} \\
\qquad\left\{\begin{aligned}
& \mathrm{Al}\left(\mathrm{BH}_{4}\right)_{3}, \mathrm{PMe}_{3}+\mathrm{NMe}_{3} \\
&+\mathrm{Al}\left(\mathrm{BH}_{4}\right)_{3}, \mathrm{NMe}_{3}+\mathrm{PMe}_{3} \\
&+\mathrm{HAl}\left(\mathrm{BH}_{4}\right)_{2}, \mathrm{PMe}_{3}+\mathrm{BH}_{3}, \mathrm{NMe}_{3} \\
&+\mathrm{HAl}\left(\mathrm{BH}_{4}\right)_{2}, \mathrm{NMe}_{3}+\mathrm{BH}_{3}, \mathrm{PMe}_{3}
\end{aligned}\right.
\end{aligned}
$$

The trimethylamine and trimethylphosphine released

17 N. N. Greenwood, E. J. F. Ross, and A. Storr, J. Chem. Soc., 1965,1400 .

${ }_{18}$ S. Ahrland, J. Chatt, and N. R. Davies, Quart. Rev., 1958, $12,265$. were present in an approximately $1: 1$ molar ratio, i.e., $\mathrm{NMe}_{3} \sim \mathrm{PMe}_{3}$, and since reactions (8a) and (8b) therefore occur to about the same extent this suggests that in the mixed $1: 2$ adduct the $\mathrm{Al}-\mathrm{N}$ and $\mathrm{Al}-\mathrm{P}$ bond strengths are comparable. The relative bond strengths of the aluminium-ligand atom bond therefore appears to be $\mathrm{N} \sim \mathrm{P}>\mathrm{As}$ and $\mathrm{O}>\mathrm{S}$.

Compared with the previous results for aluminium compounds ${ }^{18}$ the $\mathrm{N}-\mathrm{P}$ relationship is anomalous, as is the order of stability in the $1: 2$ adducts where $\mathrm{P}>\mathrm{N}$. The most obvious reasons for the relative instability of the nitrogen compound is steric strain. The structure of aluminium borohydride-trimethylamine, as determined by $X$-ray diffraction, ${ }^{19}$ indicates that there is probably interference between the bridging hydrogen atoms and the hydrogen atoms of the methyl groups. Such interaction would presumably be increased in the $1: 2$ adduct if the borohydride groups return to their planar positions about the aluminium. For the $1: 2$ trimethylphosphine adduct the larger covalent radius of the phosphorus atom ${ }^{20}$ (single bond covalent radius of $\mathrm{P}=1 \cdot 10 \AA$, and $\mathrm{N}=0.70 \AA$ ) may well be sufficient to lessen such interaction so that the phosphorus is stabilised relative to the nitrogen compound.

\section{EXPERIMENTAL}

Aluminium borohydride, and the various $1: 1$ adducts were prepared as previously described. ${ }^{1}$

Preparation of Aluminium Borohydride-Triphenylphosphine.-Aluminium borohydride $(0 \cdot 366 \mathrm{~g} ., 5 \cdot 12 \mathrm{mmoles})$ was condensed on to a frozen solution of triphenylphosphine (1.34 g., 5.12 mmoles) in toluene $\left(25 \mathrm{ml}\right.$.) at $-196^{\circ}$. Reaction occurred as the toluene was allowed to melt slowly, there being in that portion of the solution which had melted always an excess of unreacted aluminium borohydride. The white crystalline product was only slightly soluble in aliphatic and aromatic hydrocarbon solvents. The product was involatile, and difficulty in purification was avoided by carefully purifying the starting materials (Found: $\mathrm{Al}, 4 \cdot 54$; hydrolysable $\mathrm{H}, 1 \cdot 1 ; \mathrm{BH}_{3} \mathrm{PPh}_{3}, 88.2 \%$; $M, 325$. $\mathrm{C}_{18} \mathrm{H}_{27} \mathrm{AlB}_{3} \mathrm{P}$ requires $\mathrm{Al}, 4.54$; hydrolysable $\mathrm{H}$, $\left.1.05 ; \mathrm{BH}_{3} \mathrm{PPh}_{3}, 89.0 \% ; M, 333\right)$.

Pyrolysis of Aluminium Borohydride-Triphenylphosphine. -The adduct $(1.26 \mathrm{~g} ., 3.77 \mathrm{mmoles})$ was heated at $70^{\circ}$ for $3 \mathrm{hr}$, volatile material being removed continuously in vacuo and trapped at $-196^{\circ}$. Aluminium borohydride $(0.133 \mathrm{~g}$., 1.86 mmoles) was obtained (identified from its i.r. spectrum) together with trace quantities of a white solid and diborane. The white involatile residue was washed with benzene to remove borane-triphenylphosphine (identified from its i.r. spectrum and melting point), leaving a greyish residue, insoluble in organic solvents and reacting violently with water, but insufficient of the insoluble material was produced for a reliable analysis.

Pyrolysis of Aluminium Borohydride.-A gaseous sample was heated at $80^{\circ}$ for several days in a sealed bulb. A slight white deposit had formed at the end of this time, but analysis of the vapour showed only a little diborane with

19 N. A. Bailey, P. H. Bird, and M. G. H. Wallbridge, Chem. Comm., 1966, 286.

20 L. Pauling, "The Nature of the Chemical Bond," Cornell Univ. Press, Ithaca, 1960, p. 224. 
most of the aluminium borohydride remaining undecomposed. No further change occurred after heating at $120^{\circ}$ for a further $12 \mathrm{hr}$. Further, when the borohydride was heated at $80^{\circ}$ for several hours in an i.r. gas cell only a trace of diborane was detected when the i.r. spectrum was recorded at $80^{\circ}$.

Reaction of Aluminium Borohydride with Excess of Triphenylphosphine.-Triphenylphosphine $\quad(0.94 \quad$ g., $\quad 3.61$ mmoles) was stirred with aluminium borohydride $(0.128 \mathrm{~g}$., $1.79 \mathrm{mmoles})$ in isopentane $\left(30 \mathrm{ml}\right.$.) at $0^{\circ}$ for $5 \mathrm{hr}$. After removal of the solvent, $0.496 \mathrm{~g}$. of the residual material was dissolved in $48.66 \mathrm{~g}$. of benzene, the freezing point of which had been previously determined. The depression $\left(0.158^{\circ}\right)$ indicated a molecular weight, of the material in solution, of 315. The molecular weight of $\mathrm{Al}\left(\mathrm{BH}_{4}\right)_{3}, 2 \mathrm{PPh}_{3}$ is 595 , and the molecular weight after reaction (5) would be expected to be $595 / 2$, i.e., 297.5 , assuming that the $\left[\mathrm{H}_{2} \mathrm{AlBH}_{4}\right]_{n}$ was completely insoluble. After filtration of the solution and removal of the solvent the residue showed an i.r. spectrum identical with that of borane-triphenylphosphine.

Reaction of Aluminium Borohydride with Ammonia.(a) Formation of the 1:2 adduct. Ammonia (0.0575 g., 3.38 mmoles) was added to a stirred solution of aluminium borohydride $(0 \cdot 243 \mathrm{~g} ., 3.4 \mathrm{mmoles})$ in toluene at $-78^{\circ}$. A white solid $0.154 \mathrm{~g}$., equivalent to 1.46 mmoles of $\mathrm{Al}\left(\mathrm{BH}_{4}\right)_{3}, 2 \mathrm{NH}_{3}$, precipitated from solution. The volatile material was removed from the solid and treated with further ammonia $(0.0575 \mathrm{~g}$., $3.38 \mathrm{mmoles})$ at $-78^{\circ}$ when further solid, whose i.r. spectrum was identical with that of the first solid, was precipitated.

(b) Reaction with excess of ammonia. A tensiometric titration was made by adding ammonia to a stirred solution of aluminium borohydride $(0 \cdot 173 \mathrm{~g}$., $2.42 \mathrm{mmoles})$ in toluene $\left(50 \mathrm{ml}\right.$.) at $-78^{\circ}$. The vapour pressure of the mixture was recorded at $0^{\circ}$ after each addition of ammonia at $-78^{\circ}$. No increase in the vapour pressure was observed until 6 equiv. of ammonia had been added. The toluene and excess of ammonia were removed in vacuo, to yield a residual white powder (Found: $\mathrm{Al}, 15.7$; hydrolysable $\mathrm{H}$, $6 \cdot 03 ; \mathrm{B}, 21 \cdot 2 ; \mathrm{NH}_{3}, 60 \cdot 0 . \mathrm{H}_{30} \mathrm{AlB}_{3} \mathrm{~N}_{6}$ requires $\mathrm{Al}, 15 \cdot 6$; hydrolysable $\mathrm{H}, 6.9 ; \mathrm{B}, 19 \cdot 1 ; \mathrm{NH}_{3}, 59.0 \%$ ). An $X$-ray powder diffraction photograph of this solid showed no sharp lines, and the material was therefore assumed to be amorphous.

Reaction of Aluminium Borohydride Hexa-ammine with Alkali Metals in Ammonia.-A similar reaction was observed for both lithium and sodium, but lithium was preferred since one of the products (lithium borohydride) was more soluble in ether than the sodium analogue. Thus, the hexa-ammine $(0 \cdot 050 \mathrm{~g} ., 0 \cdot 286 \mathrm{mmole})$ was dissolved in liquid ammonia $\left(20 \mathrm{ml}\right.$.) and allowed to react at $-40^{\circ}$ with lithium metal $(0.004$ g., 0.572 mmole). The lithium was completely consumed (the blue colour of the solution being discharged), and hydrogen $(6.3 \mathrm{ml}$. at s.t.p., $0 \cdot 281 \mathrm{mmole})$ was evolved. After removal of the ammonia the colourless residue was extracted with ether. Lithium borohydride, identified by its i.r. spectrum, was eluted, and the residue, which was insoluble in ether and hydrocarbon solvents, was analysed [Found: Al, 27.8; hydrolysable $\mathrm{H}, 8 \cdot 2$; $\mathrm{B}, \mathbf{2 3 \cdot 3}$; $\mathrm{NH}_{2}, 32 \cdot 2 ; \mathrm{Li}$ (semiquantitatively), 5.0. $\mathrm{H}_{12} \mathrm{AlB}_{2} \mathrm{LiN}_{2}$ requires $\mathrm{Al}, 27 \cdot 8$; hydrolysable $\mathrm{H}, 8.25 ; \mathrm{B}, 22.7 ; \mathrm{NH}_{2}$, $33 \cdot 0 ; \mathrm{Li}, 7 \cdot 17 \%]$.

Preparation of I : 2 Adducts of Aluminium Borohydride.(a) With trimethylamine. Finely ground aluminium boro- hydride-trimethylamine $(0 \cdot 146 \mathrm{~g} ., 1 \cdot 01 \mathrm{mmoles})$ was allowed to react at $-78^{\circ}$ with trimethylamine $(0.077$ g., 1.31 mmoles). After about $30 \mathrm{~min}$. the excess of trimethylamine was removed at $-78^{\circ}, 0.012 \mathrm{~g} \cdot(0 \cdot 20 \mathrm{mmole})$ being recovered. Under these conditions the competitive cleavage reaction is avoided. On warming the flask to $-15^{\circ}$ decomposition of the white solid product commenced as indicated by the evolution of borane-trimethylamine $(0.042$ g., $0.575 \mathrm{mmole})$ and trimethylamine $(0 \cdot 015 \mathrm{~g} ., 0.415 \mathrm{mmole})$ both of which were identified by their i.r. spectrum. A pure sample of borane-trimethylamine was volatile at $-25^{\circ}$ in vacuo, and it appears therefore that none of this compound was present in the original reaction product.

(b) With trimethylphosphine. This was similar to that described above for the trimethylamine product. Trimethylphosphine (and the borane adduct) could only be removed slowly from the solid in vacuo at room temperature. The 1: 2 adduct was obtained as a white solid (Found: $\mathrm{Al}$, $12 \cdot 1$; hyderolysable $\mathrm{H}, 5 \cdot 4 ; \mathrm{B}, \mathbf{1 5 \cdot 5} . \mathrm{C}_{6} \mathrm{H}_{30} \mathrm{AlB}_{3} \mathrm{P}_{2}$ requires Al, 12.1; hydrolysable $\mathrm{H}, 5 \cdot 4 ; \mathrm{B}, 14.5 \%$ ). Both this and the trimethylamine adduct were insoluble, or decomposed, in typical organic solvents.

Displacement Reactions.-(a) Aluminium borohydridedimethyl sulphide and dimethyl ether. Aluminium borohydride-dimethyl sulphide $(0.171 \mathrm{~g} ., 1.28 \mathrm{mmoles})$ was treated with dimethyl ether (0.055 g., 1.20 mmoles) at room temperature. After $30 \mathrm{~min}$. material volatile at $-10^{\circ}$ was removed, and identified as dimethyl sulphide $(0.072 \mathrm{~g}$., $1 \cdot 16$ mmoles), contaminated with a slight trace of dimethyl ether, from the i.r. spectrum of the vapour.

(b) Aluminium borohydride-trimethylarsine and trimethylphosphine. In a similar reaction to that above, aluminium borohydride-trimethylarsine $(0.122 \mathrm{~g}, 0.637 \mathrm{mmole})$ was treated with trimethylphosphine $(0 \cdot 212 \mathrm{~g}$., $0.278 \mathrm{mmole})$. After reaction at room temperature trimethylarsine $(0 \cdot 030$ g., $0 \cdot 253$ mmole) was recovered.

(c) Trimethylamine and trimethylphosphine adducts. A number of reactions were performed in which the conditions (e.g., presence or absence of solvent, toluene, and different proportions of the reactants) were varied. The method was similar to that discussed above. In all cases a mixture of cleavage products, borane-trimethylamine and -trimethylphosphine, was separated in vacuo at $10^{\circ}$ from the other reaction products, and the i.r. spectra of the mixtures of these two products show that the molar quantities of each present were always about the same. This was deduced by comparison with a spectrum of pure samples of each mixed in a 1: 1 molar ratio.

Preparation and Decomposition of the Mixed $1: 2$ Adduct, Aluminium Borohydride-Trimethylamine-Trimethylphosphine.-Aluminium borohydride-trimethylphosphine $(0 \cdot 206$ g., 1.39 mmoles) was treated with trimethylamine $(0 \cdot 123 \mathrm{~g}$., 2.08 mmoles) at $-78^{\circ}$. After standing for 30 min. trimethylamine $(0.040 \mathrm{~g} ., 0.68 \mathrm{mmole})$ was recovered. On warming the $1: 2$ adduct to $-10^{\circ}$ a mixture of trimethylamine and trimethylphosphine was removed in vacuo. A comparison of the i.r. spectrum of this mixture with one obtained from a 1:1 mixture of the ligands showed that the ligands were recovered in about a $1: 1$ molar ratio.

Reaction of Aluminium Borohydride-Trimethylamine with Borane-Trimethylphosphine.-The two reactants aluminium borohydride-trimethylamine $(0.078 \mathrm{~g} ., 0.60 \mathrm{mmole})$ and borane-trimethylphosphine $(0.026 \mathrm{~g} ., 0.29 \mathrm{mmole})$ were stirred in toluene solution for $1 \mathrm{hr}$. at room temperature. After rapid removal of the solvent at $-20^{\circ}$ the solid 
Inorg. Phys. Theor.

volatile at $0^{\circ}$ was found to be only borane-trimethylphosphine.

Analysis.-Active hydrogen was determined gas-volumetrically after hydrolysis of a sample with $2 \mathrm{M}$-hydrochloric acid in a sealed-off bulb fitted with a break-seal. The bulb was heated at $50^{\circ}$ for $12 \mathrm{hr}$. to ensure complete hydrolysis. Aluminium in the resulting solution was precipitated as the 8-hydroxyquinolinate, and boron determined by titration as the mannitol complex. $\mathrm{NH}_{2}$ was present in the hydrolysis product as $\mathrm{NH}_{4}{ }^{+}$, and the ammonia liberated on making the solution alkaline was distilled into standard hydrochloric acid and determined by back titration. Lithium was precipitated as lithium uranyl acetate. All the triphenylphosphine appeared in the hydrolysis product as boranetriphenylphosphine, $\mathrm{BH}_{3}, \mathrm{PPh}_{3}$, a white insoluble air-stable solid which was filtered off, dried, and weighed.

We thank the S.R.C. for a maintenance grant (to P. H. B.).

[6/1282 Received, October 11th, 1966] 